IRA-International Journal of Management \& Social Sciences

ISSN 2455-2267; Vol.03, Issue 03 (2016)

Institute of Research Advances

http://research-advances.org/index.php/RAJMSS

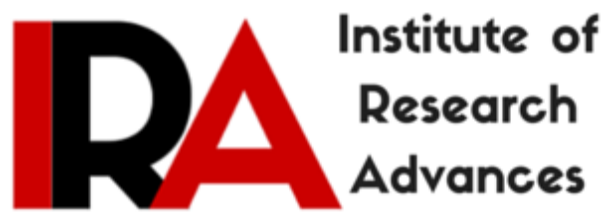

\title{
A Study on Customer's opinion with regard to Online Shopping
}

Mr. Pavan. K. A,

Research Scholar,

G R Damodaran Academy of Management, Coimbatore, India.

Dr. N. Nirmaladevi,

Professor,

G R Damodaran Academy of Management, Coimbatore, India.

DOI: http://dx.doi.org/10.21013/jmss.v3.n3.p14

How to cite this paper:

K. A, P., \& Nirmaladevi, D. (2016). A Study on Customer's opinion with regard to Online Shopping. IRA-International Journal of Management \& Social Sciences (ISSN 2455-2267), 3(3). doi:http://dx.doi.org/10.21013/jmss.v3.n3.p14

(C) Institute of Research Advances

(cc) EY-NC

This works is licensed under a Creative Commons Attribution-Non Commercial 4.0 International License subject to proper citation to the publication source of the work.

Disclaimer: The scholarly papers as reviewed and published by the Institute of Research Advances (IRA) are the views and opinions of their respective authors and are not the views or opinions of the IRA. The IRA disclaims of any harm or loss caused due to the published content to any party. 


\begin{abstract}
After the shopping mall revolution the next big wave is online shopping and it has been started in a big way. One of the world's largest online shopping companies has entered and giving a tough competition for home grown players. Educated young people welcomed the online shopping format with two hands. The objective of the study is to understand the purchasing pattern, opinion regarding the service quality, ease of use, security and payment process etc., Online customers are booming day by day and creating rush in online sites. Supply chain and delivery services became more vibrant to establish on time delivery. These changes initiate changes in the customer choices and behavior and that of their purchasing pattern. This paper highlights the customer choices and opinion with regard to online shopping. The results of the study may seed to a deep study about online shopping behavior of the customers.
\end{abstract}

\title{
Key words
}

Online shopping, customers, service quality, Ease of use, Security and payment process

\section{Introduction}

E - Commerce is big business and getting bigger every day. The most popular ecommerce categories are non durables in an online survey intends to purchase clothing or make airline or hotel reservations using an online device. There is a paradigm shift in the customers mind set after the entry of online markets. This shift brings in changes in the customers shopping behaviour and their needs and wants. Marketer's approaches and strategies are also changing to cater the needs and wants of the customers. This study explores in general about the customers opinion on online shopping in India. The results of the survey give a research outlook in dealing with the customers opinion with regard to online shopping trends.

\section{About Online shopping}

Online shopping behaviour (also called online buying behaviour and internet shopping/buying behavior) refers to the process of purchasing products or services via internet. The process consists of five steps similar to those associated with traditional shopping behaviour (liang and lei 2000). In the typical online shopping process, when potential consumers recognize a need for some merchandise or service, they go to the internet and search for need-related information. However, rather than searching activity, at time potential consumers are attracted by information about product or services associated with the felt need. They then evaluate alternative and choose the one that best fits their criteria for meeting the felt need. Finally, a transaction is conducted

Online shopping is done through an online shop, e-store, internet shop or online store. All the products in online stores are described through text, with photos and with multimedia files. Many online stores will provide links for extra information about their products. They often make available, safety procedures,instructions, manufacture specification and demonstration. 


\section{Review of literature}

Monsuwe, dellaert and ruyter (2004) in their study used the technology acceptance model (TAM) as the basis. From the finding author suggest that consumers attitude towards internet shopping first depends on the direct effect of relevant online shopping features. Online shopping features can be either consumer's perceptions of the functional and utilitarian dimension like- ease of use, and -usefulness, or their perception of emotional and hedonic dimension like-enjoyment.

From the Bannergy, dutta and guptha (2010) study it can be infer that $89.9 \%$ where satisfied and $96.1 \%$ satisfied customers also intended to indulge in online shopping in the future also, the researcher also revealed that there was a significant association between online shopping and monthly family income, frequency of internet usage and time spend per session on internet use.

Dhevika V.P.T, latasri O.T.V, S, karmugil (2014) the most important factor influencing online shopping is- security, followed by - trust worthy shopping and - website design/features and the least important factor influencing is - bargaining shopping, there is no significant association between security and website design/features of the respondents and their overall online buying behaviour. But there is a significant association between trust worthy shopping, informed shopping, effortless shopping, experiential shopping, bargain shopping, time saving and convenient shopping of the respondent and their overall buying behaviour

Bellman, lohse and Johnson (1999) examine the relationship among demographics, personal characteristics, and attitudes towards online shopping. These authors find that people who have a more wired lifestyle and who are more time-constrained tend to buy online more frequently,I,e.,those who use the internet as a routine tool and / or those who are more time starved prefer shopping on the internet.

\section{Objective of the study}

- To study the consumer's opinion on online shopping.

- To find the relationship between frequency of online shopping and factors of purchase decision.

- To find the relationship between amount spent in online shopping andfactors of purchase decision.

\section{Research Methodology}

The nature of the research is descriptive and the goal of the study is to explore the consumer's opinion towards online shopping and measure how these factors are extensive. For this reason, a survey was conducted in Neelambur area to collect primary data by using questionnaire which contains 11 nominal scale question and 16 likert scale questions regarding online shopping. A convenient sampling process has been used to collect data for the research. Quantitativeanalysis has been used to analyze the data. All questions areclose- ended because all the possible answers were given to the respondents. The likert scale has been used for the main research questions 90 questionnaires where distributed to young adults ages ranging from 20 to30. 78 questionnaires where received and 70 questionnaires are only eligible for further analysis.reliability test has under gone got a cronbach's alpha value of .882 this shows the reliability of the instrument 
In this study four variables were taken which are service quality, ease of use, security and payment process to understand the consumer'sopinion in online shopping.

\section{$\underline{\text { Service Quality }}$}

Service quality has a direct impact on consumer in keeping strong and loyal relationship with the online retailers. Online retailers with excellent service quality have the advantage of learning about their customer's expectations, thus improving their satisfaction (khrishianto et al.,2012) n this study the service quality refers to the websites ability to serve the customer like easily understanding the navigation layout and screen position in the online shopping

\section{Ease of use}

It deals with ease of gaining information needed. Well working of the website. User friendliness and working of the linked page well this all are this all are very much needed in the online shop inning

\section{$\underline{\text { Security }}$}

One of the crucial factors in the online world is security. Security is defined as the ability of the website to protect personal information of the customers from any un authorized use of information disclosure during electronic transaction (Gue et al.,2012) In this study we deal with level of confidence in giving payment details like credit card information, customer's opinion about security.

\section{Payment processing}

It deals with the consumer opinion about the satisfaction level in the payment process. Like acceptance about the payment process by the website. Ease of the payment process and choice of the payment options.

\section{Analysis and Findings}

Demographic variables considered for the study are shown in percentage in the following table.

\begin{tabular}{|c|c|c|c|}
\hline Demographic Factors & Classifications & Frequency & Percentage \\
\hline \multirow{2}{*}{ Gender } & Male & 41 & $58.6 \%$ \\
\hline & Female & 29 & $41.4 \%$ \\
\hline \multirow[t]{2}{*}{ Age } & $<20$ & 13 & $18.6 \%$ \\
\hline & 20 to $30 \mathrm{yrs}$ & 57 & $81.4 \%$ \\
\hline \multirow[t]{3}{*}{ Time spend in internet } & $<2$ hours & 30 & $42.9 \%$ \\
\hline & $2-4$ hours & 19 & $27.1 \%$ \\
\hline & $4<$ hours & 21 & $30 \%$ \\
\hline \multirow[t]{4}{*}{ Shopping Experience } & $<1$ year & 20 & $28.6 \%$ \\
\hline & 2 to 3 year & 35 & $50 \%$ \\
\hline & 3 to 4 year & 12 & $17.1 \%$ \\
\hline & $4<$ & 3 & $4.3 \%$ \\
\hline \multirow{3}{*}{$\begin{array}{l}\text { Frequency of online } \\
\text { purchase }\end{array}$} & Once in a month & 43 & $61.5 \%$ \\
\hline & Twice in a month & 22 & $31.4 \%$ \\
\hline & More than three times & 5 & $7.1 \%$ \\
\hline
\end{tabular}




\begin{tabular}{|c|c|c|c|}
\hline & in a month & & \\
\hline \multirow{4}{*}{$\begin{array}{l}\text { Monthly cash spent on } \\
\text { online shopping }\end{array}$} & $<1000$ & 27 & $38.6 \%$ \\
\hline & 1001 to 2000 & 27 & $38.6 \%$ \\
\hline & 2001 to 3000 & 7 & $10 \%$ \\
\hline & 3001 and above & 9 & $12 \%$ \\
\hline \multirow[t]{4}{*}{ Mode of payment } & Debit card & 10 & $14.3 \%$ \\
\hline & Credit card & 3 & $4.3 \%$ \\
\hline & Net banking & 6 & $8.6 \%$ \\
\hline & Cash on delivery & 51 & $72.9 \%$ \\
\hline \multirow{3}{*}{$\begin{array}{l}\text { Instrument used for online } \\
\text { purchase }\end{array}$} & Smart phone & 48 & $68.6 \%$ \\
\hline & Lap top & 18 & $25.7 \%$ \\
\hline & Desk top & 4 & $5.7 \%$ \\
\hline \multirow{2}{*}{$\begin{array}{l}\text { Complaint during online } \\
\text { purchase }\end{array}$} & Yes & 24 & $34.3 \%$ \\
\hline & No & 46 & $65.7 \%$ \\
\hline
\end{tabular}

From the table it can be inferred that gender wise male dominate with $58.6 \%$. in the age category 20 to 30 years having maximum count of $81.4 \%$. Regarding the time spent in internet $42.9 \%$ are in the category of less than 2 hours. In the online shopping experience $50 \%$ are 2 to 3 years experience. For the frequency of online purchase $61.5 \%$ are purchasing once in a month.77.2\% people spent around 2000 rupees in a month for online purchase.72.9\% choose cash on delivery as a mode for payment. $68 \%$ people prefer smart phone as an instrument for online purchase.65.7\% people don't have any complaint during online purchase

\section{Chi-Square Tests}

Chi square test is applied to test the association between attributes and the results are as follows:-

\section{Time spent in internet and frequency of online purchase}

- Ho: there is no significant association between time spent in internet and frequency of online purchase

- H1: there is significant association between time spent in internet and frequency of online purchase

\begin{tabular}{|l|l|l|l|}
\hline & Value & DF & $\begin{array}{l}\text { Asymp. Sig. } \\
(2 \text {-sided) }\end{array}$ \\
\hline $\begin{array}{l}\text { Pearson Chi-Square } \\
\text { Likelihood Ratio }\end{array}$ & $9.314^{\mathrm{a}}$ & 4 & .054 \\
Linear-by-Linear & .0482 & 4 & .050 \\
Association & 70 & 1 & .842 \\
N of Valid Cases & 70 & & \\
\hline
\end{tabular}

a. 3 cells (33.3\%) have expected count less than 5. The minimum expected count is 1.36 .

Inference

- The above table shows the pearson Chi-square value is 9.314 , is not finding the association with the variables of time spent in internet and frequency of online purchase. 
- The $\mathrm{P}$ value with respect to Chi-Square is 0.054 level of significance which is above the level of 0.05 , and hence there is no significant association between time spent in internet and frequency of online purchase.

\section{Time spend in internet and cash spent monthly for online purchase}

- Ho: there is no significant association between time spent in internet and cash spent on online purchase in a month.

- H1: there is significant association between time spent in internet and cash spent on online purchase in a month.

Chi-Square Tests

Inference

\begin{tabular}{|l|l|l|l|}
\hline & Value & DF & $\begin{array}{l}\text { Asymp. Sig. } \\
(2 \text {-sided) }\end{array}$ \\
\hline Pearson Chi-Square & $3.622^{\mathrm{a}}$ & 6 & .728 \\
Likelihood Ratio & 3.938 & 6 & .685 \\
Linear-by-Linear & 1.042 & 1 & .307 \\
Association & 70 & & \\
N of Valid Cases & & & \\
\hline
\end{tabular}

- The above table shows the Pearson Chi-square value is 3.622, is not finding the association with the variables of time spent in internet and cash spent monthly on online purchase.

- The P value with respect to Chi-Square is 0.728 level of significance which is above the level of 0.05 , and hence there is no significant association between time spent in internet and cash spent monthly on online purchase.

To analyze one way- ANOVA between Frequency of purchase in a month and online buying behavior.

Null Hypothesis:

All the respondents belonging to various frequency of online shopping category has an average level of influence on online buying behavior.

Alternate Hypothesis:

All the respondent belonging to various frequency of online shopping category don't have same level of influence on online buying behavior.

\begin{tabular}{|c|c|c|c|c|c|c|c|c|}
\hline Factors & Once in & month & Twice $\mathrm{i}$ & a month & $\begin{array}{l}\text { More } \\
\text { times i }\end{array}$ & $\begin{array}{l}\text { an three } \\
\text { nonth }\end{array}$ & $\begin{array}{l}\text { F } \\
\text { value }\end{array}$ & Sig \\
\hline & Mean & SD & Mean & SD & Mean & $\mathrm{SD}$ & & \\
\hline $\begin{array}{l}\text { Service } \\
\text { quality }\end{array}$ & 4.0310 & .53854 & 4.1667 & .66468 & 3.7333 & .27889 & 1.256 & .292 \\
\hline $\begin{array}{l}\text { Ease of } \\
\text { use }\end{array}$ & 3.8279 & .67129 & 3.9636 & .61299 & 3.7200 & .62610 & .446 & .642 \\
\hline security & 3.2674 & .88033 & 3.8295 & .94613 & 3.3500 & .45415 & 2.987 & .057 \\
\hline $\begin{array}{l}\text { Payment } \\
\text { process }\end{array}$ & 3.5698 & .84749 & 4.0341 & .89408 & 3.8500 & .96177 & 2.122 & .128 \\
\hline
\end{tabular}


From the above table it is inferred that in all the four factors of online purchase decision, such as service quality, ease of use, security and payment process the sig values are0.292, $0.642,0.057$, and 0.128 respectively. Hens all the values are greater than sig value 0.050 then null hypothesis is accepted and reject the alternate hypothesis

\section{One way ANOVA between Monthly spending and online buying behaviour}

Null Hypothesis:

All the respondents belonging to various category of monthly spending on online shopping has an average level of influence on various aspects of online buying behavior.

Alternate Hypothesis:

All the respondent belonging to various category of monthly spending on online shopping don't have same level of influence on online buying behavior.

\begin{tabular}{|l|l|l|l|l|l|l|l|l|l|l|}
\hline Factors & \multicolumn{2}{|l|}{ Below 1000 } & \multicolumn{2}{l|}{1001 to 2000} & \multicolumn{2}{l|}{2001 to 3000} & \multicolumn{2}{l|}{3001 and above } & $\begin{array}{l}\text { F } \\
\text { value }\end{array}$ & Sig \\
\hline & Mean & SD & Mean & SD & Mean & SD & Mean & SD & & \\
\hline $\begin{array}{l}\text { Service } \\
\text { quality }\end{array}$ & 3.9506 & .58983 & 4.0617 & .57762 & 4.2857 & .44840 & 4.1481 & .60349 & .751 & .526 \\
\hline $\begin{array}{l}\text { Ease of } \\
\text { use }\end{array}$ & 3.7778 & .68911 & 3.8889 & .61603 & 4.0857 & .78194 & 3.8667 & .53852 & .438 & .727 \\
\hline Security & 3.2315 & 1.01414 & 3.6111 & .85579 & 3.7857 & .98349 & 3.3611 & .54645 & 1.162 & .331 \\
\hline $\begin{array}{l}\text { Payment } \\
\text { process }\end{array}$ & 3.6389 & .89156 & 3.8981 & .88595 & 3.8929 & 1.04938 & 3.4167 & .71807 & .872 & .460 \\
\hline
\end{tabular}

From the above table it is inferred that in all the four factors of online purchase decision, such as service quality, ease of use, security and payment process the sig values are $0.526,0.727,0.331$, and 0.460 respectively. Hens all the values are greater than sig value 0.050 then null hypothesis is accepted and reject the alternate hypothesis.

\section{Results}

Most of the respondents belonging to the age group of 20 to 30 years and majority of them are male. Regarding the internet usage majority of them are using for at least 2 hours on daily basis. Respondents having an average 2 to 3 years of online shopping experience, most of them purchase once in a month and spends less than or around rupees 2000/-per month.Smart phone is the most preferred online plat form for making online ordering cash on delivery is the most preferred payment mode and most of the respondents don't have any complaint through online shopping. Cash spent monthly on online shopping and frequency of online shopping doesn't have any significant association with time spent in internet. From the opinion of online customers it can be identifiedthat frequency of purchase and amount spent monthly on online purchase has an average level of influence with service quality, ease of use, security and payment process. All four factors are considered equally with regard to online shopping purchase factors from the point of view of the customers.

\section{Conclusion.}

As online shopping is an emerging form of e-commerce business and is flourishing in all Business to Business and Business to Consumer business. Customer finds it as a convenient way when compared to the conventional shopping form. Even then the 
customers may not give up their willingness to purchase through the conventional shops for certain category of the product forms. From the results of the study, it is revealed that the purchase behaviour of the customers and it is found that majority of the customers spend enough time in internet for online purchase, they also spend some considerable amount through online shopping. They are conscious in purchase factors such as service quality, ease of use, security and payment process while they purchase online. Hence it is understood that, as online shopping is booming, A to $\mathrm{Z}$ products are to be available online, it is the marketers task to design the marketing strategy in such a way it catches the customer touch points.

\section{References}

- Monsuwe, T.P.Y, Dellaert, B.G.C., \&Ruyter, K.D., (2004). What Drives Consumers to Shop Online? A Literature Review. International Journal of Service Industry Management, 15 (1), 102-121

- Banerjee, N., Dutta, A., \&Dasgupta, T., (2010). A Study on Customers' Attitude Towards Online Shopping - An Indian Perspective. Indian Journal of Marketing, 40 (11), 43- 52.

- Dhevika V.P.T, LatasriO.T.V, S.Karmugil.,(2014). Factors Influencing Online Buying Behaviour In Tiruchirappalli District-Researchjournali's Journal of Marketing, Vol. 2 | No. 4 June | 2014 ISSN 2348-0947

- Bellman, S., Lohse, G., and Johnson, E. Predictors of online buying behavior, Communications of the ACM (42:12), 1999, pp. 32-38.

- Khristiono,w.,kertahadi,l.,andsuyadi,1.(2012).The influence if information and service on customer satisfaction and loyalty in online shopping. International journal of academic research, 4(2), 28-32.

- Guo, x., ling, k.c., and liu, m.(2012). Evaluating factors influencing customer satisfaction towards online shopping in china. Asian social science, 8 (13), 40-50. 